\title{
Nurse leaders' behaviors and its effect on nurses' attitude toward change at Main Assiut University Hospital
}

\author{
Saleh , N., M ; Al-Sayed , N ., M ; Ghallab , S ., A ; Abd Alaa , S., M. \\ Assistant Lecturer in Nursing Administration Dep. - Faculty of Nursing - Sohag University \\ Prof. of Nursing Administratio- Faculty of Nursing - Mansoura University; \\ Prof. of Nursing Administration - Faculty of Nursing - Assiut University
}

\begin{abstract}
Leader should direct subordinate creativity all of the time, to help them to become more creative and accept organizational change. This study was aimed to assess the effect of Nurse Leaders' behaviors on nurses' attitude toward change at Main Assiut University Hospital. The study subjects consists of (48) nurse leaders and (328) staff nurses who worked in medical, surgical, and ICUs units. Data collected through personal interview by using the demographic data sheet, leader's behaviors questionnaire, and organizational change questionnaire, the data collection took about four months. Reliability was high more than 0.9 for all tools. Results of the study showed that; Nurse leaders in high level, about near half of them have positive attitudes toward organizational change and about third of them have negative and neutral attitudes toward organizational change in low level of leaders behaviors. And staff nurses about half of them have positive attitudes toward organizational change in high leader behaviors and about third of them have neutral attitude toward organizational change in low leader behavior. There were a highly statistically significant difference between predominant organizational change with leader behavior among staff nurses. In the light of the study results, the following conclusions can be drawn; Nurses' leaders and staff nurses had positive attitude toward change and there are a negative correlation between leaders behaviors and attitude toward organizational change. In the light of the finding, the researcher recomended that: provide psychological support to motivate nurses to use their opinions and suggestion without fear, provide training programs to develop leaders and nurses' knowledge which helps in accepting the change.
\end{abstract}

\section{Keywords: Leadership, Leader Behaviors, And Organizational Change.}

\section{Introduction:}

Leading and managing organizational change has become an essential knowledge base and skill set required in both public and private sector organizations. Not only must leaders and managers deal with the technical, process, and operational aspects of change, but they must also understand the psychology or human side of change as they engage others in change initiatives (Synnot and Fitzgerald, 2007).

Good leaders develop through a never ending process of self-study, education, training, and experience (Gillies 1994 and Javitch, 2009). Nurse leaders must change their behavior to suit the profile of new breed of workers. There are six leader behaviors which include; consideration, initiating structure, persuasiveness, tolerance of freedom, production emphasis, and predictive accuracy, (Redfern, et al., 2003).

Nurse leaders have the opportunity to actively participate in shaping the future of health care and nursing practice using knowledge from the past and present. The future nurse leader will need new leadership skills and styles that are different from those used in the past to be successful in the environment of the future, (Perra, 2000). There are five factors that influence leadership development: personal life factors; self-confidence; influence of significant people; progression of experiences; and success, and innate leader qualities and tendencies. (Kerfoot, 2001\& 2006)

Change is a natural social process of individuals, groups, organizations, and society and it is the process of moving from one system to another (Roussel 2006). Change should be implemented only for good reasons, because human beings have little control over many changes in their lives. (Sullivan \&Decker, 2005).

Change is necessary for growth. The health care system is changing with nurses' contributions. Leaders initiate change followers survive it. Nurse leaders must become skilled in implementing change introduced by the broad of directors (Marquis\& Huston, 1996).

Organizational change upsets individuals and groups throughout the entire organization. The effect of organization change on each employee depends on the individual's values, position in the work group, and psychological dependence on Peers (Yoder-wise, 2007).

The healthcare industry has faced constant change, and the power or authority of the change agent has impact on the strategy of change (Kerfoot, 2001). 
The appropriate strategy for any situation depends on the power of the change agent and the amount of resistance expected from the subordinate (Marquis\& Huston, 2004). Change agent is the person who seeks to induce or create change (Heidemthal, 2004). This person may originate the ideas for change or may be an individual who recognizes the value of new ideas originated by others. (Mahoney, 2001).

The first rule of change agent is to begin any process of change with concern for its impact on nurses, so leaders $\backslash$ managers must devise ways for responding effectively to these feelings. This may involve engaging employees more actively in change efforts, communicating with them more frequently and comprehensively about new developments, creating a forum for them to vent their frustrations and fears, or simply maintaining an "open door" environment. (Smith, et, al. 2005)

\section{Significance of the Study}

There are many studies was done about leadership styles, leadership skills, and leadership roles with job satisfaction, but studies about Nurse leaders' behaviors and its effect on nurses attitudes toward change didn't take the same interest. So, the researcher thinks to pursue this study.

\section{Aim of study}

This study aimed to assess the effect of nurse leaders' behaviors on attitude toward change for nurses leader and staff nurses at Main Assiut University Hospital.

\section{Study Question}

Is there a relation between nurse leaders' behaviors and (nurses' leaders and staff nurses) attitudes toward organizational change?

\section{Subjects and Method}

\section{1-Technical Design.}

Involves the research design, setting, subjects and tools of data collection

A) Research Design;

Descriptive correlational design was used to carry out the present study.

B) Setting:

The study was conducted at six general surgical units with bed capacity 154; Six general medical units with bed capacity 196 ; and four intensive care units, (CCU, trauma ICU, postoperative ICU, and general ICU)with bed capacity 58. at Main Assiut university hospital.

C) Subjects:

The present study includes all staff nurses and nurses leaders who are working in the previous mentioned units, the total study subjects were (376) divided as follows:
- Nurses leaders' 48 includes :( one nurse director; five assistants' director; forty two nurses' leader.)

- All staff nurses working in the selected units (n = 328) distributed as follows: 80 staff nurses at general surgical units, 98 staff nurses at general medical units and $\mathbf{1 5 0}$ staff nurses at Intensive care units.

D) Data Collection Tools.

Three different tools were used to collect study data include the following:

\section{(1) Demographic data sheet}

to measure; sex, age, educational level, and years of experience in nursing, units, and data about attending training about leadership, or change.

\section{(2) Leader's Behaviors Questionnaire}

Developed by (Stogdll, 1963) and modified by (Zanaty, 1994). It includes 40 items divided into; 6 factors related to leaders' behaviors: Initiating structure 7 items; Tolerance of freedom $\mathbf{6}$ items; Consideration 8 items; Production emphasis 8 items; Predictive accuracy $\mathbf{4}$ items; Persuasiveness $\mathbf{7}$ items.

To measure nurse leaders' behaviors, the response to each item was on a five points Likert scale ranging from; (5 = always occurred; 4 = sometimes; 3 = don't know; 2 = rarely; and $\mathbf{1}=$ not occurred). Cut point at $60 \%$ and above means high leader behavior score toward change and below $60 \%$ mean low.

(3) Organizational Change questionnaire:

Developed by, (Bovey \& Hede, 2001). And includes 40 items related to nurse attitudes toward the change, which describe nurse leaders and staff nurses beliefs, behaviors and feelings during processes of change includes three categories: acceptance, fear, and cynicism. The responses were on a five points Likert scale ranging from; ( $5=$ strongly agree; 4 = agree; 3 = in between; 2 = disagree; and $1=$ strongly disagree).

If scoring $60 \%$ or more, there was a high attitude toward change, and if less than $60 \%$ there was low attitude toward change.

The reliability of the study tools clarified in this table.

\begin{tabular}{|l|c|c|}
\hline \multicolumn{1}{|c|}{ Scale } & $\begin{array}{c}\text { No. of } \\
\text { items }\end{array}$ & $\begin{array}{c}\text { Crombach } \\
\text { alpha coefficient }\end{array}$ \\
\hline Leader's Behaviors & 40 & 0.90 \\
\hline $\begin{array}{l}\text { Organizational } \\
\text { Change }\end{array}$ & 40 & 0.87 \\
\hline
\end{tabular}

\section{2-Administrative Design;}

- An official approval to carry out the study was obtained from responsible persons in the hospital (hospital director, nursing director, and heads of departments). 


\section{3-Operational Design:}

A) Preparatory Phase.

After reviewing the available literatures concerning to the topic of the study, modification of the study tools was done and then Arabic translation and validity was done. This phase took about three months from January, to March, 2010

\section{B) Pilot Study:}

A pilot study was fulfilled to test feasibility, understandability, and clarity of the study tools. It was carried out on (4) Nurses leaders' and (28) staff nurses selected from units not included in the study. Data collected from the pilot study were analyzed, reviewed and used in making necessary modifications prior to the final application of the study tools. The duration of this phase took about one month through April 2010.

C) Filed Work:

After ensuring the clarity of the tools, the actual data collection from nurses' leaders' and staff nurses done by personal interview. Each interview took about 15 mints, started with clarifying the aim of study and interpretation if needed. The whole duration of data collection took about four months from May to August, (2010).

\section{4- Statistical Design:}

\section{Statistical Analysis}

Data entry and statistical analysis were done using SPSS 14.0 statistical software package. Data were presented using descriptive statistics in the form of frequencies and percentages for qualitative variables, and means and standard deviations for quantitative variables. Qualitative categorical variables were compared using chi-square test. Whenever the expected values in one or more of the cells in a $2 \times 2$ tables was less than 5, Fisher exact test was used instead. In larger than $2 \times 2$ cross-tables, no test could be applied whenever the expected value in $10 \%$ or more of the cells was less than 5. Pearson correlation analysis was used for assessment of the interrelationships among quantitative variables. Statistical significance was considered at p-value $<0.05$.

\section{Results:}

The aim of this study was assessing the effect of Nurse Leaders' behaviors on nurses' attitude toward change at Main Assiut University Hospital.

Table 1. Personal characteristics of the study sample :

\begin{tabular}{|l|l|l|l|l|}
\hline \multirow{2}{*}{ Personal characteristics } & \multicolumn{2}{|c|}{ Nurse leaders (n=48) } & \multicolumn{2}{c|}{ Staff nurses (n=328) } \\
\cline { 2 - 6 } & Frequency & Percent & Frequency & Percent \\
\hline Age (years): & & & & \\
\hline$<25$ & - & & 103 & 31.4 \\
\hline $25-$ & 22 & 45.8 & 97 & 29.6 \\
\hline $30+$ & 26 & $\mathbf{5 4 . 2}$ & 128 & $\mathbf{3 9 . 0}$ \\
\hline Range & $24.0-49.0$ & & $19.0-59.0$ & \\
\hline mean \pm SD & $31.9 \pm 5.9$ & & $29.0 \pm 7.2$ & \\
\hline Sex: & \multicolumn{3}{|l}{} & \\
\hline Male & - & & 40 & 12.2 \\
\hline Female & 48 & 100 & 288 & $\mathbf{8 7 . 8}$ \\
\hline Unit: & & & & \\
\hline General units (Medical \& Surgical) & 19 & 39.6 & 143 & 43.6 \\
\hline Intensive care units & 29 & $\mathbf{6 0 . 4}$ & 185 & $\mathbf{5 6 . 4}$ \\
\hline Educational qualification: & & & & \\
\hline Secondary diploma & - & - & 292 & $\mathbf{8 9}$ \\
\hline Specialty diploma & - & - & 17 & 5.2 \\
\hline Technical institute diploma & - & - & 19 & 5.8 \\
\hline Bachelor & 41 & $\mathbf{8 5 . 4}$ & - & - \\
\hline Postgraduate (master - doctoral) & 7 & 14.6 & - & - \\
\hline Years of Experience: & & & & \\
\hline$<5$ & - & & 59 & 18.0 \\
\hline
\end{tabular}




\begin{tabular}{|l|l|l|l|l|}
\hline \multirow{2}{*}{ Personal characteristics } & \multicolumn{2}{|l|}{ Nurse leaders (n=48) } & \multicolumn{2}{c|}{ Staff nurses (n=328) } \\
\cline { 2 - 6 } & Frequency & Percent & Frequency & Percent \\
\hline $5-$ & 32 & $\mathbf{6 6 . 7}$ & 132 & 40.2 \\
\hline $10+$ & 16 & 33.3 & 137 & $\mathbf{4 1 . 8}$ \\
\hline Range & $3.0-21.0$ & & $0.0-40.0$ & \\
\hline mean \pm SD & $9.5 \pm 5.0$ & & $10.3 \pm 6.6$ & \\
\hline Attendance of training courses at work about: & & & & \\
\hline Creativity & - & - & - & - \\
\hline Change & - & - & - & - \\
\hline Leadership & $\mathbf{1 2}$ & $\mathbf{2 5 . 0}$ & 12 & 3.7 \\
\hline
\end{tabular}

figure 1 . Leaders' behavior as perceived by the study sample

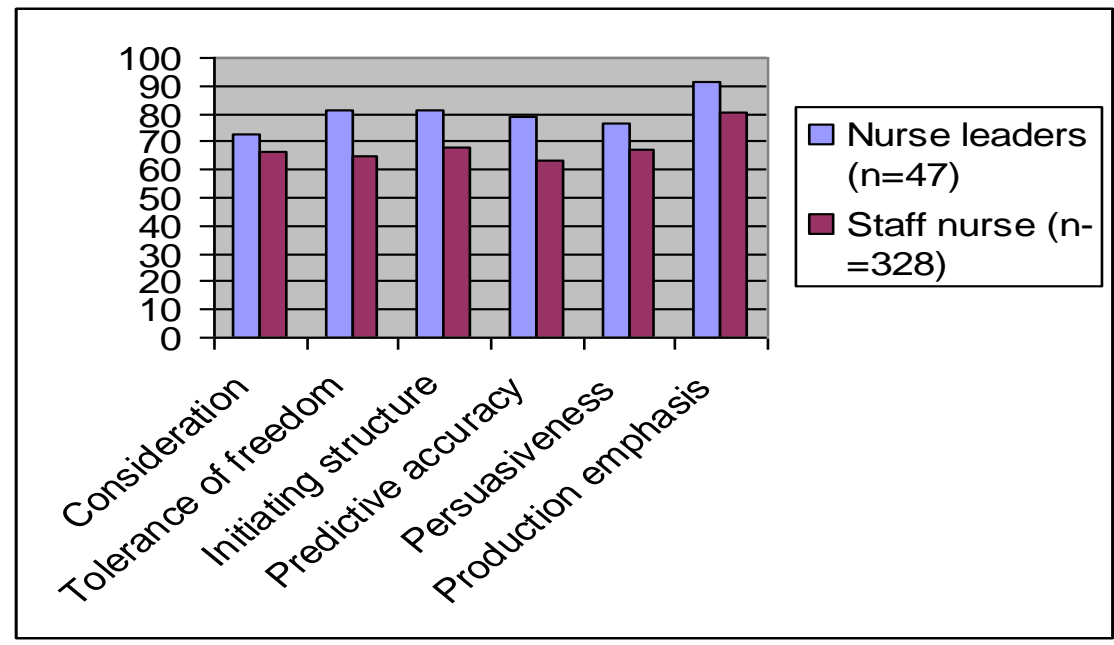

figure 2. Predominant organizational change of the study sample

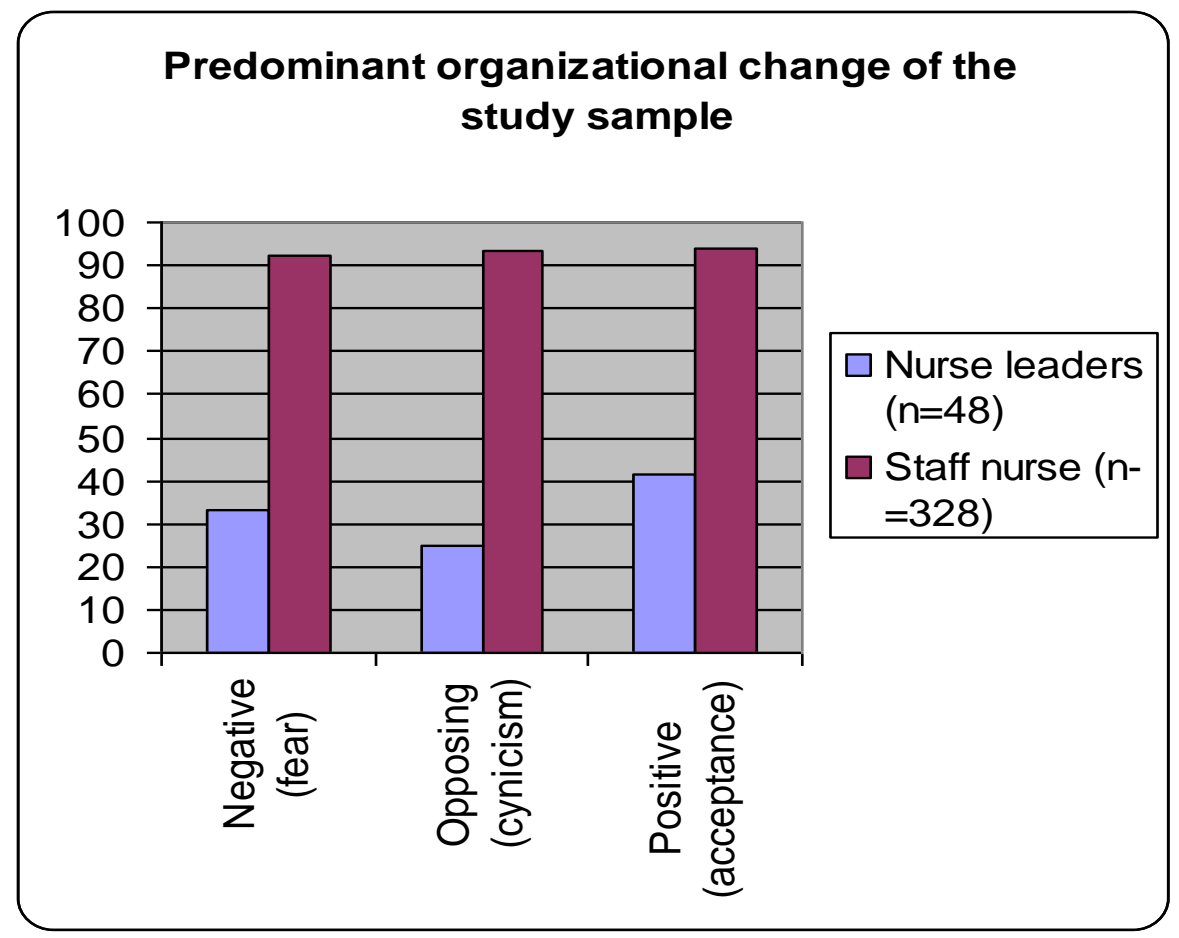




\section{Results:}

Personnel characteristics of the study sample.

Table (1) describes that, for nurses leaders, majority of them have bachelor degree of nursing science $(85.4 \%)$, with less than five years of experience in their job (66.7\%), aged more than 30 years old (54.2\%), working at intensive care units $(60.4 \%)$, and only about quarter of them (25\%) attended training course at work in leadership

On the same line for staff nurses, the majority of them were female $(87.8 \%)$, have secondary technical nursing school (81.2\%), with years of experience ranged from 5 to more than 10 years in their job $(40.2 \%$ and $41.8 \%)$ respectively, (39\%) were more than 30 years old, $(56.4 \%)$ working at intensive care units, only (3.7\%) having attended training course at work about leadership.

figure (1); show that, leaders' behavior of the study sample. (For nurse director) as perceived by nurse leaders, was high for all items (83\%), ranged from (91.5\%) for Production emphasis to $(72.3 \%)$ for Consideration. While (for head nurses) as perceived by staff nurses, were about two third of staff nurses perceptions were that's head nurses have a high leaders behavior for all items (65.2\%), ranged from (80.5\%) for Production emphasis to $(63.1 \%)$ for Predictive accuracy.

figure (2) declares that, predominant organizational change of the study subject. About $(41.7 \%)$ of nurse leaders' and $(93.9 \%)$ of staff nurses have positive attitude toward change.

Relation between leaders behaviors with predominant organizational change of the study sample, Table (2); indicates that, among nurse leaders in high level, about (42.5\%) have positive attitudes toward organizational change. Meanwhile in low level of leaders behaviors $(37,5 \%)$ from nurse leaders have negative and neutral attitudes toward organizational change.

On the other hand among staff nurses this table presents that, $(50 \%)$ have positive attitudes toward organizational change in high leader behaviors and (35.1\%) have neutral attitude toward organizational change in low leader behavior. There were a highly statistically significant difference between predominant organizational change with leader behavior among staff nurses $(\mathrm{p}<0.004)$.

Correlation between organizational change, and leaders behavior among staff nurses and nurses' leaders' personal characteristics Table (3); shows. For staff nurses, there is a negative correlation among age and experience with positive attitude of change $(-.016 ;-.033)$ and among leaders behaviors with qualification (-.097).
On the other hand, For nurse leaders' there is a positive correlation among, qualification with neutral and negative attitude of change ( .058 \& .013). Meanwhile, there is a negative correlation among age with neutral, negative, and positive attitude of change $(-.014,-.055$, \& -.055$)$ respectively; among experience with negative and positive attitude of change (-.052, \&-0.43).

\section{Discussion:}

Nurses Leaders must ensure that staff nurses have clear roles and accountabilities, as well as the authority to make necessary changes in their work. (Zhou \& George, 2003).

The present study was implemented in an attempt to assess the effect of Nurse Leaders' behaviors on nurses' attitude toward change at Main Assiut University Hospital. The study subject was (48) nurse leaders and (328) staff nurses. The highest percent of the nurses' leaders have Bachelor degree of nursing science; about two third of them have more than five years of experience in their job; slightly more than half of them aged more than 30 years old, and working at intensive care units. The result showed that, only about one quarter of them attended training course about leadership. Table (1) On the same line for staff nurses most of them were females, have diploma of secondary nursing school; more than one third of them have more than ten years of experience in their job, and their age more than 30 years old; slightly more than half of them working at intensive care units. The majority of them not attended any training courses at work, table (1). Ongoing the present study result clarified that, leaders behavior of nurse director (top management) as prescribed by nurse leaders (midlle and lower level of management), and head nurses as perceived by staff nurses, they were high leaders' behaviors. Both nurse leaders and staff nurses agreed that production emphasis is the highest percent of leader behaviors. While, the lowest percent goes to consideration item for nurse leaders and predictive accuracy item for staff nurses figure (1).

This result may be due to that's nurses feel their nurse leaders are not a friend, she doesn't Looks to their satisfaction, and does not follow the work of others, put their concentration on work only and first priority for them was to achieve the work rather than to take care of the staff, and this done with routine manner through nursing administration and hospital policies but not by concentration on efficiency of work. This result was in disagreement with Darvish \& Farzance-dokht, (2011), in their study; who reported that Leaders should create high level of communication and concerned with staff through 
behaviors and performance, because concentration on work has a negative attitude which effect on organization growth and change.

From the study finding regards to attitude of nurse leaders and staff nurses toward organizational change figure (2). The results revealed that, both nurse leaders and staff nurses perception that they had positive attitude toward change and accept change. While more than eighty percent of both nurse leaders and staff nurses need to know the importance of change in their personal characteristics to allow and apply effective change. More than three quarters of the study subjects (nurse leaders and staff nurses) reported that, lack of information about the process of change cause misconceptions in the organization. Change of behavior is very slow, and they pretend approving the change but in fact they are not allowed to reject. This result disagreed with (Bovey \& Hede, 2001) who reported that, the reason for the failure of many change in organizations is precisely individuals' resistance to the change. This fact alone justifies the analysis of people's cognitive processes as a component of organizational change.

As regards relation between predominant organizational change, and Leader behaviors in the study, there was negative relation between leader behaviors, and attitude toward organizational change table (2). This result may be attributed to that, leaders may be afraid of any mistake or blame for their behavior, which make them did not give the staff nurses a chance to be creative or give innovative ideas for updating their job, beside lack of training courses about good leader behaviors, that enhance creativity and organizational change.

As regards to correlation between nurse leaders behaviors, and organizational change among staff nurses and nurse leaders personal characteristics; there was positive correlation and high statistical significance differences among neutral attitude toward change with age, qualification, and experiences of staff nurses, table (3). This result may be attributed to that, staff nurses were young in age, have less experiences and they need more training about change and need leaders to know how to lead the process of change. This result in agreement with (Zanaty (1994); and Farmer and Tierney 2007), who reported that, leaders must have creative capabilities and characteristics to guide subordinates through change.

\section{Conclusion(s)}

In the light of the study results, the following conclusions can be drawn:

- Both nurse leaders and staff nurses had high level of leaders' behaviors and positive attitudes toward organizational change.

- Both nurse leaders and staff nurses had a negative correlation between leaders' behaviors with organizational change.

\section{Recommendation(s)}

Consequently based upon such results, the following recommendations were desirable:

1- Provide psychological support to motivate nurses to explore their opinions and suggestions without fear.

2- Nurses should be given an opportunity for participation in decisions, which affect their practical and educational growth

3- Provide training programs to develop the leadership abilities of nurse leaders and staff nurses to develop positive attitude toward organizational change.

Table 2. Relation between leaders' behaviors, and predominant organizational change of the study sample :

\begin{tabular}{|c|c|c|c|c|c|c|c|c|c|c|c|c|}
\hline \multirow{4}{*}{ Items } & \multicolumn{6}{|c|}{ Nurse leaders $(n=48)$} & \multicolumn{6}{|c|}{ Staff nurses $(n=328)$} \\
\hline & \multicolumn{4}{|c|}{ Leaders behaviors } & \multirow{3}{*}{$\mathbf{X}^{2}$} & \multirow{3}{*}{$\begin{array}{c}\text { p- } \\
\text { value }\end{array}$} & \multicolumn{4}{|c|}{ Leaders behaviors } & \multirow{3}{*}{$\mathbf{X}^{2}$} & \multirow{3}{*}{ p-value } \\
\hline & \multicolumn{2}{|c|}{ High } & \multicolumn{2}{|c|}{ Low } & & & \multicolumn{2}{|c|}{ High } & \multicolumn{2}{|c|}{ Low } & & \\
\hline & No. & $\%$ & No. & $\%$ & & & No. & $\%$ & No. & $\%$ & & \\
\hline $\begin{array}{l}\text { Organizational } \\
\text { change } \\
\text { (predominant): }\end{array}$ & & & & & & & & & & & & \\
\hline Negative (fear) & 7 & 17.5 & 3 & 37.5 & & & 63 & 29.4 & 36 & 31.6 & & \\
\hline $\begin{array}{l}\text { Neutral } \\
\text { (cynicism) }\end{array}$ & 16 & 40.0 & 3 & 37.5 & $\begin{array}{l}\text { Fish } \\
\text { er }\end{array}$ & 0.69 & 44 & 20.6 & 40 & 35.1 & $\begin{array}{l}10 . \\
92\end{array}$ & $0.004 *$ \\
\hline $\begin{array}{l}\text { Positive } \\
\text { (acceptance) }\end{array}$ & 17 & 42.5 & 2 & 25.0 & & & 107 & 50.0 & 38 & 33.3 & & \\
\hline
\end{tabular}

(*) Statistically significant at $p<0.01$ 
Table 3. Correlation between organizational change, and leader's behaviors among nurses leader and staff nurses personal characteristics:

\begin{tabular}{|c|c|c|c|c|c|c|}
\hline \multirow{3}{*}{ Study variable } & \multicolumn{6}{|c|}{ Pearson correlation coefficient } \\
\hline & \multicolumn{3}{|c|}{ Staff nurses $(n=328)$} & \multicolumn{3}{|c|}{ Nurse leaders' $(n=48)$} \\
\hline & Age & Qualification" $^{\#}$ & Experience & Age & Qualification $^{\#}$ & Experience \\
\hline \multicolumn{7}{|l|}{ Organizational change } \\
\hline -Neutral & $.158^{* *}$ & $.113^{*}$ & $.131^{*}$ & -.014 & .058 & .000 \\
\hline -Negative & .050 & .058 & .033 & -.055 & .013 & -.052 \\
\hline -Positive & -.016 & .042 & -.033 & -.055 & -.035 & -.043 \\
\hline Leaders behaviors & .035 & -.097 & .074 & & & \\
\hline
\end{tabular}

(*) Statistically significant at $p<0.05$

(\#) Spearman rank correlation

\section{References :}

1. Bovey, W. \& Hede, A. (2001): Resistance to organizational change: the role of cognitive and affective processes. Leadership \& Organization Development Journal, 22 (8), 372-382.

2. Darvish, H. \& Farzance-dokht, N. (2011): studying the effect of leader-member exchange in creating energy and creativity at workplace: a case study at Alzahera University. International journal of academic research. 3 (2): 1252-1257.

3. Farmer, M. And Tierney, P. (2007) Leader Behavior, Creativity, and the Creative SelfConcept, Paper for the annual meeting of the Society for Industrial and Organizational Psychology, New York Cit

4. Gillies, D. (1994): Nursing management a systems approach .3rd ed. Chapter 25, effecting change, P.p 455- 456

5. Heidemthal. P. (2004): Essentials of Nursing leadership \& management. Chapter 10. Change and conflict resolution. P.p $207-210$.

6. Javitch, G. (2009) 10 Characteristics of Superior Leaders Do you have these essential traits?

7. Kerfoot, K. (2001): The Leader as Synergist. MEDSURG Nursing, 10(2), 101-103.

8. Kerfoot, K. (2006): on leadership. The Johnny Appleseed's of organizational change. Dermatology nursing, 18(2), 208-210

9. Mahoney, J. (2001): Leadership skills for the 21st century. Journal of Nursing Management, 9: 269-71.

10. Marquis, L. \& Huston S. (1996): leadership roles and management functions in nursing, theory and application $2^{\text {nd }}$ ed unit 2. pp 76-92.

11. Marquis, L. and Huston, J. (2004): Leadership Roles and Management Functions in Nursing 6th ed. P.p 3-4, 28-29, 76.
12. Roussel, L. (2006): Management and leadership for nurse administrators, 4th ed. Chapter 4 P.p 55-65\& 164- 175.

13. Smith, C. Rebeck, S. Schaag, H. Kleinbeck, S. Moore, J. \& Bleich, M. (2005): A model for evaluating systemic change. Measuring outcomes of hospital discharge education redesign. Journal of nursing administration, 35(2), 67-73

14. Stogdll, R. (1963): Manual for the leadership behavior description questionnaire from $\mathrm{x} 11$ : an experimental revision. Bureau of Business research Ohio state univ. Columbus, Ohio

15. Sullivan, E. \&Decker, P. (2005): Effective management in nursing, $7^{\text {th }}$ ed Learning key skills in nursing management pp 431-352

16. Synnot, B., and Fitzgerald, R. (2007): The Toolbox for Change. Practical Approach, Danjugah Pty, Brisbane, Australia

17. Yoder- wise, P. (2007): Leading and Management in Nursing, 4th ed. Pp 3-14, 93.

18. Zanaty, R. ( 1994): Effect leader behavior on subordinate innovative thinking (1), scientific journal Tanta university

19. Zhou, J. \& George, M. (2003): Awakening employee creativity: The role of leader emotional intelligence, The Leadership Quarterly 14 (3) 545-568 